\title{
Spatial distribution of Yellow Sigatoka Leaf Spot correlated with soil fertility and plant nutrition
}

\author{
A. S. Freitas' ${ }^{1}$ E. A. Pozza' ${ }^{1}$ M. C. Alves' ${ }^{2}$. \\ G. Coelho' ${ }^{2}$ H. S. Rocha ${ }^{3}$ A. A. A. Pozza ${ }^{4}$
}

(C) Springer Science+Business Media New York 2015

\begin{abstract}
This study analyzed the spatial distribution of Yellow Sigatoka Leaf Spot relative to soil fertility and plant nutritional status using geostatistics. The experimental area comprised 1.2 ha, where 27 points were georeferenced and spaced on a regular grid $18 \times 18 \mathrm{~m}$. The severity of Yellow Sigatoka, soil fertility and plant nutritional status were evaluated at each point. The spherical model was adjusted for all variables using restricted maximum likelihood. Kriging maps showed the highest infection rate of Sigatoka occurred in high areas of the field which had the highest concentration of sand, while the lowest disease was found in lower areas with lower silt, organic matter, total exchangeable bases, effective cation exchange capacity, base saturation, $\mathrm{Ca}$ and $\mathrm{Mg}$ in soil, and foliar sulfur (S). These results may
\end{abstract}

M. C. Alves

marcelocarvalhoalves@gmail.com

A. S. Freitas

aurivan.soares@hotmail.com

E. A. Pozza

eapozza@ufla.br

G. Coelho

coelho@deg.ufla.br

H. S. Rocha

herminio.rocha@embrapa.br

A. A. A. Pozza

adeliapozza@gmail.com

1 Plant Pathology Department, Federal University of Lavras, PO Box 3037, Lavras, MG CEP 37200-000, Brazil

2 Engineering Department, Federal University of Lavras, PO Box 3037, Lavras, MG CEP 37200-000, Brazil

3 Embrapa Cassava and Fruits, Rua Embrapa s/n, PO Box 007, Cruz das Almas, BA CEP 44380-000, Brazil

4 Department of Soil Science, Federal University of Lavras, PO Box 3037, Lavras, MG CEP 37200-000, Brazil 
help farmers manage Yellow Sigatoka disease more effectively, with balanced fertilization and reduced fungicide application. This practice minimizes the environmental impact and cost of production while contributing to production sustainability.

Keywords Banana - Geostatistics - Mineral nutrition $\cdot$ Mycosphaerella musicola

\section{Introduction}

Banana (Musa spp.) is a major tropical fruit that is rich in protein and carbohydrates, and low in fat (Mohamed et al. 2011). World banana production in 2012 was 102 million tons with the largest producers being India, China, Philippines, Ecuador, and Brazil (Faostat 2014). Production could be even higher if it wasn't for the reduced yield from Yellow Sigatoka, a fungal disease caused by Mycosphaerella musicola Leach (Rocha et al. 2012). The disease occurs widely in many producing areas where it causes losses from premature death of leaves, reduced growth and development of plants, and lowered fruit quality (Castelan et al. 2013).

Yellow Sigatoka is difficult to control. Chemical control and the use of resistant varieties is recommended. Despite their simplicity and efficiency, chemicals are hazardous to the environment when used extensively and increase the cost of production. Genetic control, despite being efficient and environmentally friendly is not generally available and often produces unpalatable fruit without strong commercial appeal by consumers (Cordeiro and Matos 2005).

Other disease management practices, such as adequately nourishing plants, have been investigated recently (Lima et al. 2010; Uchôa et al. 2011) to reduce the use of fungicides when growing consumer acceptable varieties. Plants with balanced nutrition have rapid leaf emergence and shoot production at shorter intervals. In addition, physical and chemical resistance improve as horizontal resistance is expressed (Taiz and Zeiger 2013).

Studying the relationship of disease with nutritional status of plants in the field, especially along the planting area, requires an appropriate methodology. As classical statistics does not consider spatial dependence in many methods, it has been replaced by geostatistics. This approach generates more consistent responses to epidemiological aspects of plant diseases because of the aggregate pattern of inoculum and disease, and soil variability in the area (Alves et al. 2006). Geostatistics is part of the geographic information system and is one of the most applied techniques to study spatially related data (Alves et al. 2009; Lamichhane et al. 2013; Li et al. 2013). Its application has rapidly expanded in the area of epidemiology and plant disease management (Alves et al. 2009), especially for spatial pattern analysis of factors associated with plant diseases, such as mineral nutrition (Pinheiro et al. 2008; Uchôa et al. 2011).

Given the importance of Yellow Sigatoka in banana plantations and the lack of information on its epidemiology relative to the mineral nutritional status of plants, this study investigated the spatial distribution of Yellow Sigatoka relative to soil fertility and the nutritional status of plants.

\section{Materials and methods}

The experiment was conducted between November 2011 and October 2012 at the Vale dos Ventos farm, Lavras, state of Minas Gerais, at geographical coordinates $21^{\circ} 08^{\prime} 42^{\prime \prime}$ South latitude and $45^{\circ} 01^{\prime} 37^{\prime \prime}$ West longitude. Banana variety Prata-Anã had very severe Yellow 
Sigatoka without implementing control measures, thus disease behavior could be studied under natural conditions. The experimental area comprised 1.2 ha, where 27 sample points spaced on an $18 \times 18 \mathrm{~m}$ grid (Fig. 1) were georeferenced. The geographical coordinates of each point were determined using GPS Trimble 4600 LS.

The severity of Yellow Sigatoka, soil fertility and plant nutritional status were evaluated at each georeferenced point. Disease severity was assessed once a month for the same plant using the diagrammatic scale proposed by Stover (1972) and modified by Gauhl (1994). All selected plants were at the same developmental stage, with an average height $2.5 \mathrm{~m}$ and 10-11 photosynthetically active leaves.

The infection rate (ii) of each plant was calculated using the equation:

$$
\text { ii }=[\Sigma n * b /(N-1) * T] * 100,
$$

where $\mathrm{n}$ is the number of leaves at each scale level; $\mathrm{b}$ is the scale degree; $\mathrm{N}$ is the number of degrees in the scale and $\mathrm{T}$ is the total number of evaluated leaves.

Soil fertility was assessed by combining four soil samples (0-20 mm depth) using augers in a circle around the clump, at equidistant points $90^{\circ}$ at each georeferenced point. A sample of about $500 \mathrm{~g}$ was sent to the soil analysis laboratory at the Department of Soil Science, Federal University of Lavras (UFLA) to determine chemical and physical properties of the soil.

Nutritional status of selected plants was determined by sending 10-25 cm of tissue from the median blade of the third leaf from the apex (Martinez et al. 1999) to the laboratory of leaf analysis at the Department of Chemistry, UFLA for analysis of macronutrient and micronutrient content.

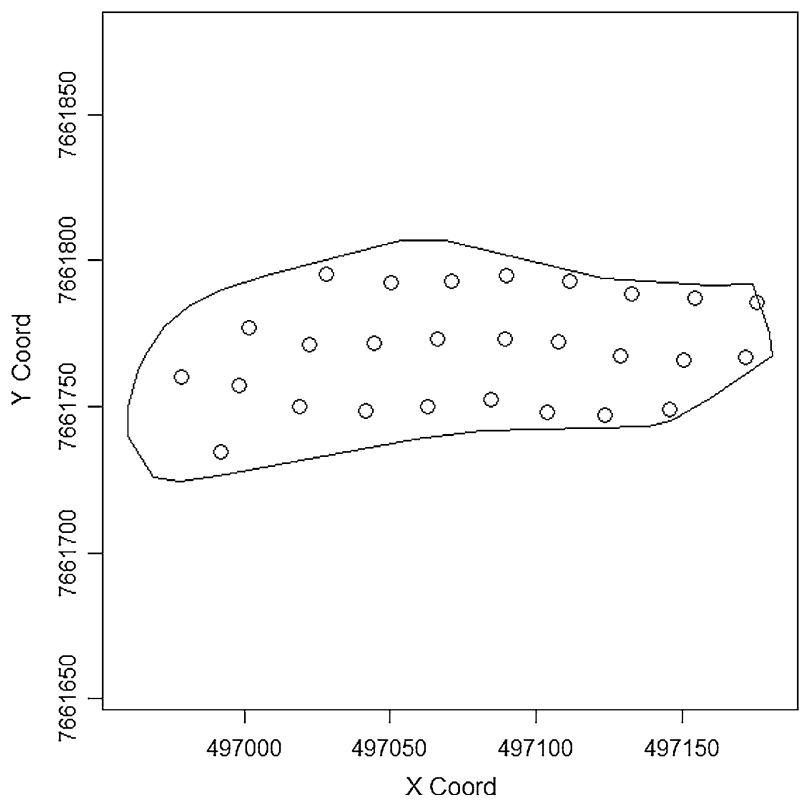

Fig. 1 Georeferenced sampling grid used to assess the severity of Yellow Sigatoka, soil fertility and the nutritional status of the plants 

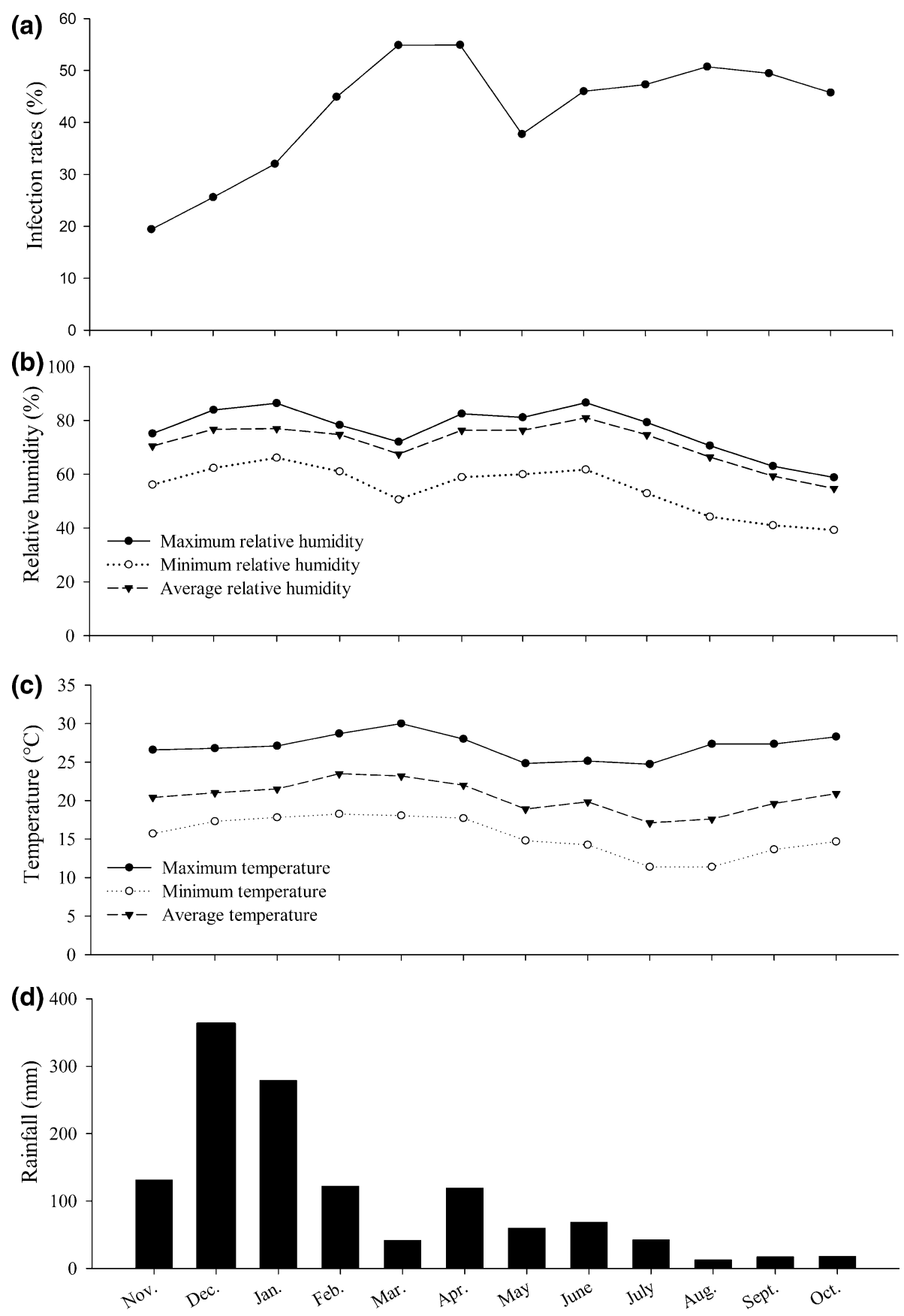

Fig. 2 Progress curve of the average infection rates of Yellow Sigatoka (a), minimum, average, and maximum relative humidity (b), minimum, average, and maximum temperature (c) and accumulated rainfall (d) between November 2011 and October 2012 
Before starting the trial, a computerized meteorological station (Datalogger-CR510, Campbell Scientific Inc., Logan, UT, USA) was installed in a metallic tower in the center of the experimental area with sensors positioned $1.5 \mathrm{~m}$ above ground level. Data collected were minimum, average, and maximum relative humidity (\%), minimum, average, and maximum temperature $\left({ }^{\circ} \mathrm{C}\right)$, and rainfall $\left(\mathrm{mm}_{\text {day }}{ }^{-1}\right)$.

Soil fertility, nutritional status of plants, and climatological data were compared by Pearson correlations using PROC CORR in SAS.

Geostatistical analysis was used to describe the spatial variability and choose the variogram model and fitting method that best described data variability. Spatial dependence was assessed under the intrinsic stationary assumption using variogram analysis (Burrough and McDonnell 1998).

The maximum likelihood method of estimation was used because the number of sampling points was less than 100 (Alves et al. 2011; Webster and Oliver 2007; PardoIgúzquiza 1998). Several isotropic functions were fitted by restricted maximum likelihood (REML), but spherical functions (Olea 2003) provided better fits.

$$
\text { Spherical }=\gamma(h)=\left\{C_{0}+C\left(\frac{3 h}{2 a c}-\frac{1}{2}\left(\frac{h}{a}\right)^{3}\right) \quad \begin{array}{c}
0 \leq h<a \\
h \geq a,
\end{array}\right.
$$

where, $C_{0}$ is the nugget effect, $C_{0}+C$ is the sill of the spatially correlated component, $a$ is the range of spatial dependence and $\mathrm{h}$ is the separating distance.

After adjustment of variograms, ordinary kriging interpolation was performed to estimate variable values for places where variables were not measured based on adjacent values (Alves et al. 2006). Geostatistical analysis was performed using R geoR (Diggle and Ribeiro 2007).

\section{Results and discussion}

The average infection rate of Yellow Sigatoka showed positive growth through the evaluations. The lowest value (19.41\%) was found in November 2011 and the highest (54.93\%) in April 2012. Relative humidity, temperature, and rainfall oscillated at both times. Precipitation was the most variable, with the highest cumulative rate occurring in December 2011 (362.7 mm) and the lowest in August $2012(13 \mathrm{~mm})$. Relative humidity and temperature remained relatively constant, with an increase and a sharp increase, respectively, at the end of evaluations (Fig. 2).

Table 1 Correlation between climatic variables $\left(\mathrm{U}_{\max }\right.$, maximum relative humidity; $\mathrm{U}_{\text {aver }}$, average relative humidity; $\mathrm{U}_{\min }$ minimum relative humidity; $\mathrm{T}_{\max }$, maximum temperature; $\mathrm{T}_{\text {aver }}$, average temperature; $\mathrm{T}_{\min }$, minimum temperature; RF, rainfall) and average infection rates (ii ${ }_{\text {aver }}$ ) of Yellow Sigatoka between November 2011 and October 2012

\begin{tabular}{llllllll}
\hline & \multicolumn{1}{l}{ Climatic variables } \\
\cline { 2 - 7 } & $\mathrm{U}_{\max }$ & $\mathrm{U}_{\text {aver }}$ & $\mathrm{U}_{\min }$ & $\mathrm{T}_{\max }$ & $\mathrm{T}_{\text {aver }}$ & $\mathrm{T}_{\text {min }}$ & $\mathrm{RF}$ \\
\hline $\mathrm{ii}_{\text {aver }}$ & -0.30 & -0.26 & -0.45 & 0.33 & 0.01 & -0.20 & $-0.66^{* * *}$ \\
\hline
\end{tabular}

** Significant at $1 \%$ probability 
High precipitation rates at the beginning of the experiment (November 2011-January 2012) favored the production of initial inoculum and progress of the disease in subsequent months. However, the high rates of leaf production that were influenced by high rainfall compensated for losses caused by disease which did not occur in lower rainfall months. This fact was corroborated by the significant negative correlation between precipitation and average infection rate during the evaluations (Table 1).

Rocha et al. (2012) found similar results, with slower progress of Yellow Sigatoka in the rainy season and higher progress in the dry season. According to these authors, longer incubation periods, spore latency and higher rates of leaf initiation possibly occurred in the rainy season. Conversely, leaf initiation was lower in the dry season to increase infection rates as lesions progressed unimpeded. Wardlaw (1961) also reported higher peaks of Yellow Sigatoka infection during the dry season which had frequent occurrences of dew and a slower rate of leaf initiation.

Table 2 Chemical and physical properties of soil and foliar levels of macronutrients and micronutrients analyzed on $06 / 15 / 2012$

\begin{tabular}{|c|c|c|c|c|c|c|c|c|}
\hline \multirow{2}{*}{$\begin{array}{l}\text { Chemical properties soil } \\
\text { Maximum levels }\end{array}$} & \multicolumn{2}{|c|}{$\begin{array}{l}\mathrm{P} \\
\left(\mathrm{mg} / \mathrm{dm}^{3}\right)\end{array}$} & \multicolumn{2}{|c|}{$\begin{array}{l}\mathrm{Ca} \quad \mathrm{Mg} \\
\left(\mathrm{cmol}_{\mathrm{c}} / \mathrm{dm}^{3}\right)\end{array}$} & \multirow{2}{*}{$\begin{array}{l}\text { TEB } \\
13.5\end{array}$} & $\mathrm{CEC}_{\mathrm{E}}$ & \multirow{2}{*}{$\begin{array}{l}\text { BS } \\
(\%)\end{array}$} & \multirow{2}{*}{$\begin{array}{l}\begin{array}{l}\mathrm{SOM} \\
(\mathrm{g} / \mathrm{kg})\end{array} \\
3.7\end{array}$} \\
\hline & 19.1 & 175 & 10.7 & 4.2 & & 13.5 & & \\
\hline Minimum levels & 1.1 & 21.8 & 1.8 & 0.7 & 3.1 & 3.5 & 25.2 & 1.6 \\
\hline Average levels & 3.5 & 86.1 & 4.6 & 1.7 & 6.5 & 6.6 & 65.1 & 2.4 \\
\hline $\mathrm{CV}(\%)$ & 78.2 & 68.1 & 45.1 & 46.8 & 40.5 & 36.7 & 27.3 & 18.2 \\
\hline Physical properties soil & & $\begin{array}{l}\text { Density } \\
\left(\mathrm{kg} / \mathrm{dm}^{3}\right)\end{array}$ & & Sand & & $\begin{array}{l}\text { Silte } \\
(\mathrm{g} / \mathrm{kg})\end{array}$ & & Clay \\
\hline Maximum levels & & 1.53 & & 520 & & 390 & & 460 \\
\hline Minimum levels & & 0.98 & & 220 & & 140 & & 330 \\
\hline Average levels & & 1.35 & & 373.7 & & 232.6 & & 393.7 \\
\hline $\mathrm{CV}(\%)$ & & 8.6 & & 20.19 & & 26.7 & & 8.45 \\
\hline Foliar levels macronutrients & & $\begin{array}{l}\mathrm{N} \\
(\mathrm{g} / \mathrm{kg})\end{array}$ & $\mathrm{P}$ & $\mathrm{K}$ & & $\mathrm{Ca}$ & $\mathrm{Mg}$ & $\mathrm{S}$ \\
\hline Maximum levels & & 33.8 & 2.1 & 24.1 & & 25.6 & 6.6 & 2.5 \\
\hline Minimum levels & & 20.4 & 1.1 & 6.0 & & 3.9 & 2.1 & 1.2 \\
\hline Average levels & & 26.7 & 1.5 & 16.1 & & 9.4 & 3.4 & 1.7 \\
\hline $\mathrm{CV}(\%)$ & & 15.1 & 15.0 & 29.4 & & 60.2 & 22.1 & 16.4 \\
\hline Foliar levels micronutrients & & $\begin{array}{l}\text { B } \\
(\mathrm{mg} / \mathrm{kg})\end{array}$ & & & Mn & $\mathrm{Z}$ & & $\mathrm{Fe}$ \\
\hline Maximum levels & & 24.1 & & & 433.6 & & & 384.3 \\
\hline Minimum levels & & 5.5 & & & 148.3 & 5 & & 51.8 \\
\hline Average levels & & 14.4 & & & 279.6 & & & 126.9 \\
\hline CV (\%) & & 23.5 & & & 26.4 & & & 60.6 \\
\hline
\end{tabular}

$T E B$ total exchangeable bases, $C E C_{E}$ effective cation exchange capacity, $B S$ base saturation, $S O M$ slit, organic matter, $C V$ coefficient of variation 


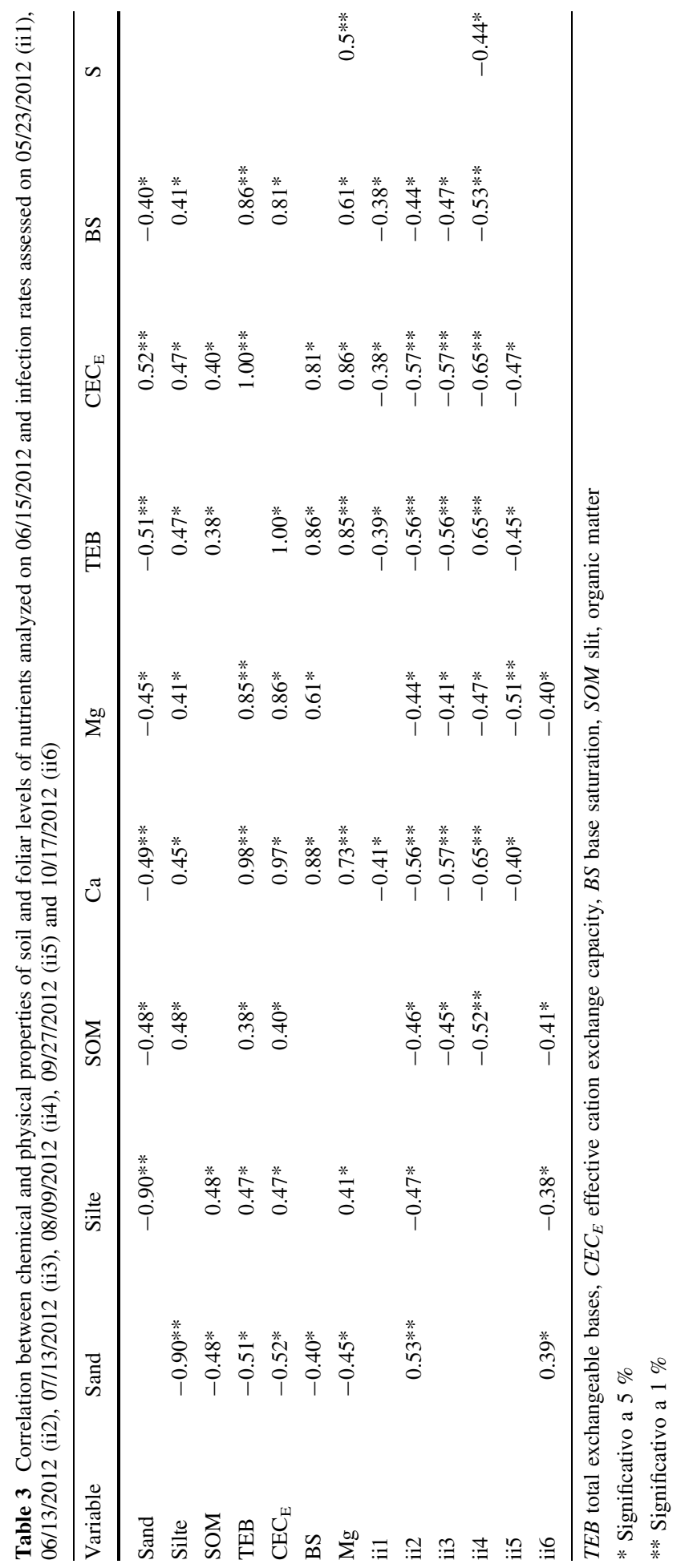


The minimum, average, and maximum levels of nutrients in soil and plants varied widely (Table 2). According to the sufficiency ranges established by Silva et al. (2002) for growing the Prata Anã banana cultivar in the north of Minas Gerais, all nutrients were below the recommended minimum except for $\mathrm{Cu}$ in leaves and $\mathrm{Mg}$ in soil. The minimum, average, and maximum leaf contents of $\mathrm{K}$ and $\mathrm{B}$ were below levels recommended by the authors.

Nutrient concentration below the sufficiency range established by Silva et al. (2002) may explain the high levels of infection throughout the evaluations, since nutrients are responsible for the expression of horizontal resistance genes and for the production of physical and chemical barriers (Marschner 2012; Taiz and Zeiger 2013).

The interaction of chemical and physical properties of soil and leaf nutrient contents with Yellow Sigatoka infection rate were significantly correlated for most of the variables at all six assessment times. The Yellow Sigatoka infection rate was positively correlated

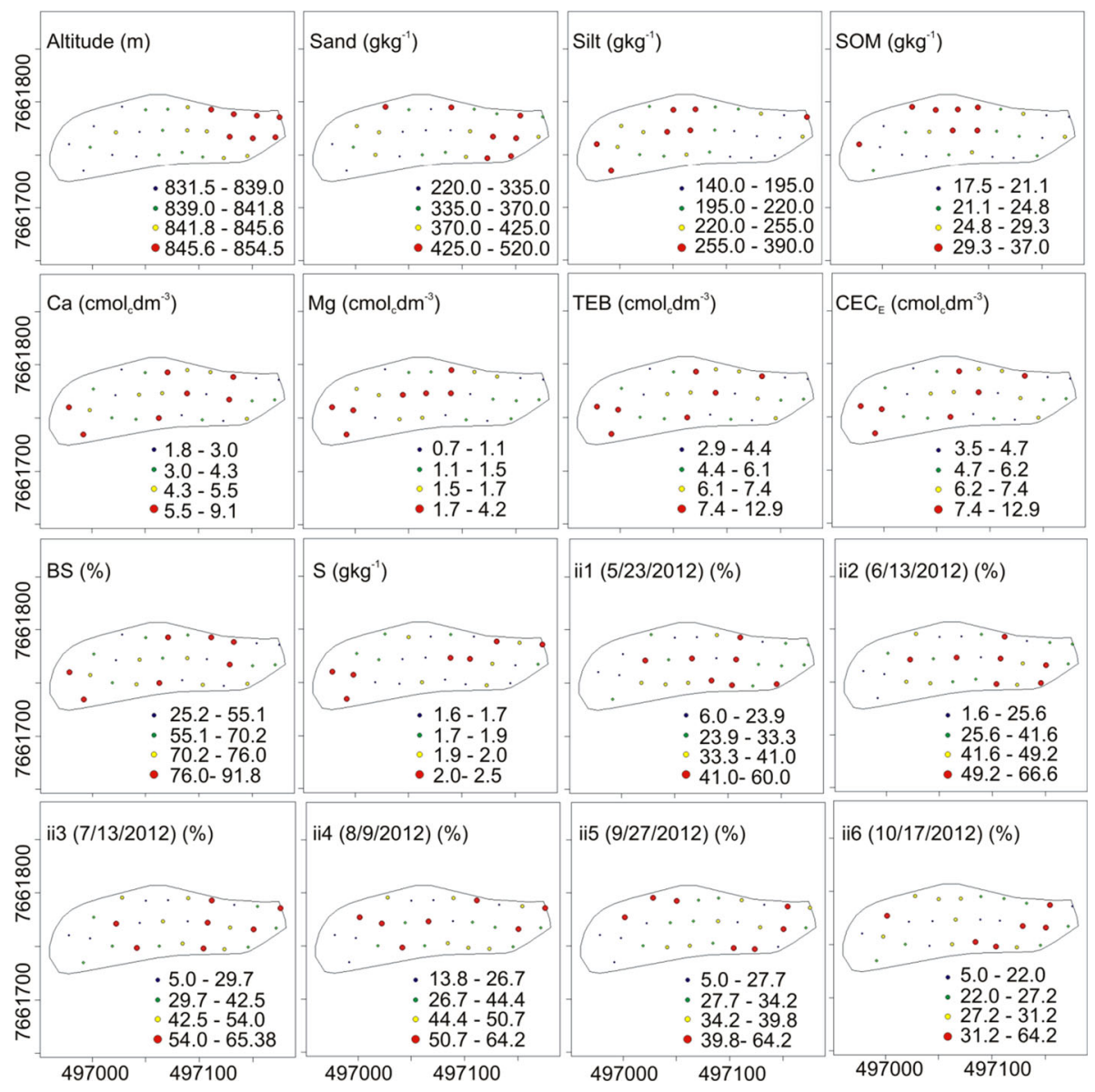

Fig. 3 Quantile maps for altitude, sand levels, organic matter (SOM), soil Ca, soil Mg, total exchangeable bases (TEB), effective cation exchange capacity $\left(\mathrm{CEC}_{\mathrm{E}}\right)$, base saturation $(\mathrm{BS})$, foliar sulfur $(\mathrm{S})$ and infection rates assessed on 05/23/2012 (ii1), 06/13/2012 (ii2), 07/13/2012 (ii3), 08/09/2012 (ii4), 09/27/2012 (ii5) and 10/17/2012 (ii6) 
with sand content, but negatively correlated with silt, organic matter (SOM), soil Ca, soil $\mathrm{Mg}$, total exchangeable bases (TEB), effective cation exchange capacity $\left(\mathrm{CEC}_{\mathrm{E}}\right)$, base saturation (BS) and foliar sulfur (S) content (Table 3).

Significant variables assessed by exploratory spatial analysis and quantile maps showed strong evidence of spatial dependence for all variables. Higher areas had higher levels of sand and lower levels of SOM, TEB and $\mathrm{CEC}_{\mathrm{E}}$. Likewise, there was a tendency for higher infection rates in areas with more sand and lower silt, SOM, TEB e $\mathrm{CEC}_{\mathrm{E}}$ (Fig. 3).

Geostatistics showed spatial dependence for all significant variables in the correlation test. The spherical model best fit the data for all variables so it was used for variogram representation and to produce kriging maps (Table 4; Figs. 4, 5). Webster and Oliver (2007) state that the spherical model is widely used in geostatistics and that it has been adjusted for diseases caused by species with an aggregated distribution pattern such as soybean cyst nematode (Heterodera glycines) (Pinheiro et al. 2008), bean anthracnose (Colletotrichum lindemuthianum) (Alves et al. 2006), and late blight (Phytophthora infestans) of potato and tomato (Jaime-Garcia et al. 2001). The nugget effect value was low for most variables (Table 4; Fig. 4). According to McBratney and Webster (1986), the nugget effect is an important variogram parameter that indicates the unexplained variability with distance of sampling. The scope showed similar or greater values than those in the sampling grid, ranging respectively from 17.71 to $142.8 \mathrm{~m}$ for $\mathrm{BS}$ and $\mathrm{Mg}$ in the soil (Table 4; Fig. 4).

The sampling grid was large enough to express spatial variability, provide a representative range and adequately capture variations (Table 4; Fig. 4). Range is a distance in which the samples are spatially correlated (McBratney and Webster 1983). Range measurement is important in experimental design and evaluation to help define the sampling procedure.

Kriging maps showed there was a higher infection rate of Yellow Sigatoka in higher parts of the terrain and in areas with more sand and less silt and organic matter (SOM) (Fig. 5). The positive correlation between infection rate and content of sand, and negative

Table 4 Spherical variogram parameters estimated by restricted maximum likelihood (REML) for chemical and physical properties of the soil, foliar levels of nutrients and infection rates assessed on $05 / 23 / 2012$ (ii1), 06/13/2012 (ii2), 07/13/2012 (ii3), 08/09/2012 (ii4), 09/27/ 2012 (ii5) and 10/17/2012 (ii6)
$T E B$ total exchangeable bases, $C E C_{E}$ effective cation exchange capacity, $B S$ base saturation, $S O M$ slit, organic matter

\begin{tabular}{llll}
\hline Variable & Nugget effect $\left(\mathrm{C}_{0}\right)$ & Sill $\left(\mathrm{C}_{0}+\mathrm{C}\right)$ & Range $(a)$ \\
\hline Altitude & 3.1 & 3.84 & 100.3 \\
Sand & 536.1 & 5296 & 70 \\
Silt & 0 & 3438 & 50.99 \\
SOM & 0 & 22.28 & 42.81 \\
Ca & 1.09 & 3.67 & 53.82 \\
Mg & 0 & 1.6 & 142.8 \\
TEB & 1.68 & 7.86 & 74.96 \\
CEC & 0.64 & 6.27 & 54.83 \\
BS & 106.3 & 216.3 & 17.71 \\
S & 0.01 & 0.05 & 105.8 \\
ii & 0 & 0.47 & 18.33 \\
ii2 & 0.17 & 0.69 & 70.76 \\
ii3 & 0.04 & 0.31 & 30.41 \\
ii4 & 0 & 0.19 & 26.34 \\
ii5 & 0.12 & 0.14 & 17.75 \\
ii6 & 0 & 0.29 & 37.27 \\
\hline
\end{tabular}



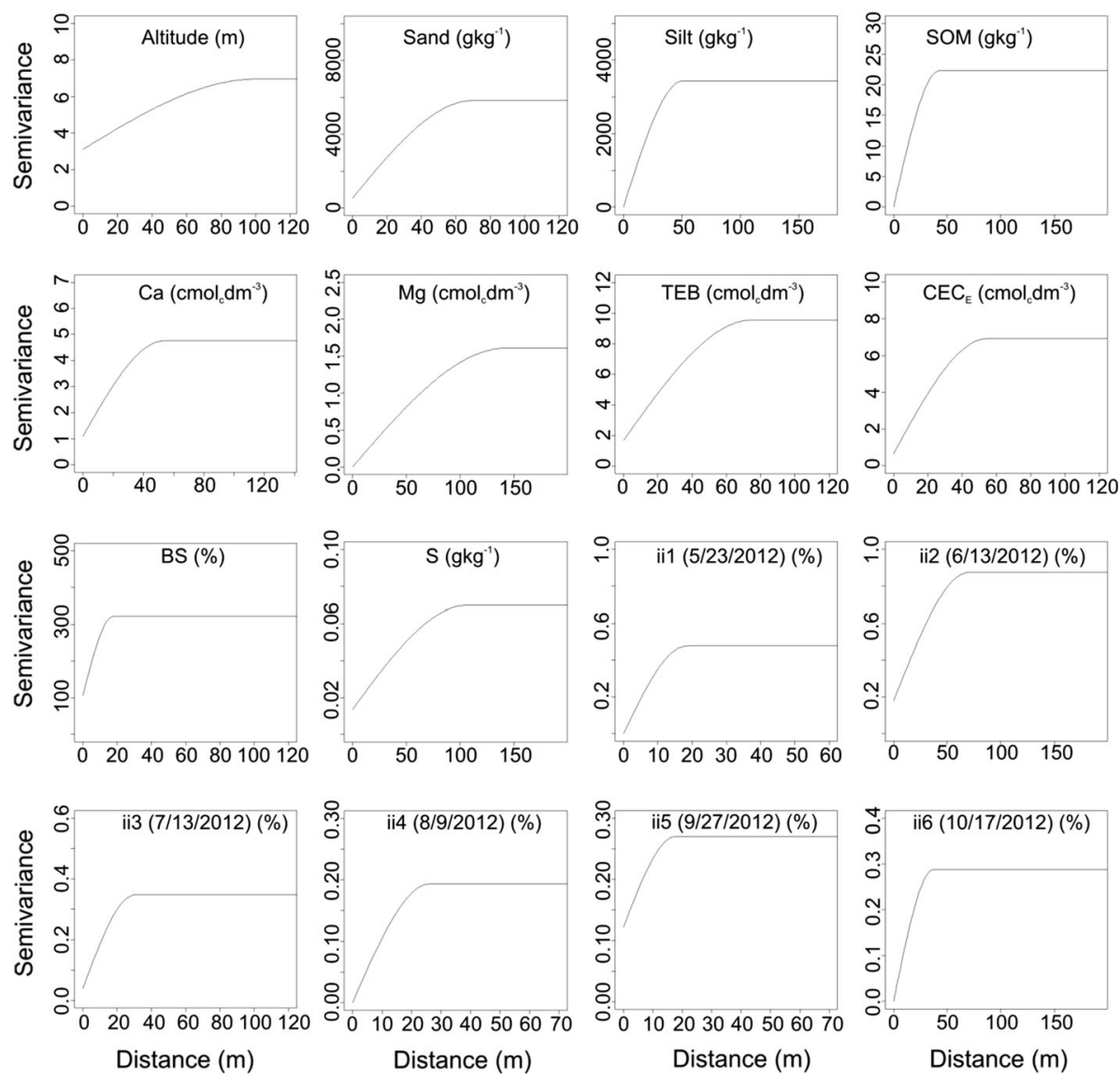

Fig. 4 Spherical variogram estimated by restricted maximum likelihood (REML) for altitude, sand levels, organic matter (SOM), soil Ca, soil Mg, total exchangeable bases (TEB), effective cation exchange capacity $\left(\mathrm{CEC}_{\mathrm{E}}\right.$ ), base saturation (BS), foliar sulfur (S), and infection rates assessed on 05/23/2012 (ii1), 06/13/2012 (ii2), 07/13/2012 (ii3), 08/09/2012 (ii4), 09/27/2012 (ii5) and 10/17/2012 (ii6)

correlation with silt and organic matter (Table 3) show the importance of these soil properties in growth and development of plants. Soils with a high content of sand and low content of silt and organic matter have less ability to retain water and nutrients so they are prone to pathogen infection and disease. Soils with a high content of silt, clay and organic matter have a greater capacity for retaining water and nutrients (Silva et al. 1999), to provide favorable conditions for plant growth and the expression of disease resistance (Marschner 2012; Taiz and Zeiger 2013). Silva et al. (2007) reported a similar result in banana plantation where higher yield was achieved on soils with higher clay and organic matter contents and yield was lower on soils with more sand.

TEB, $\mathrm{CEC}_{\mathrm{E}}$, and $\mathrm{BS}$ are highly related to the content of sand, silt, and soil organic matter. Furtini Neto et al. (2001) reported that these attributes tend to increase as soils have lower contents of sand and higher contents of silt, clay and organic matter. In no tillage farming, Cavalcante et al. (2007) found increased cation exchange capacity (CEC) and improvement in soil chemical conditions was due to the significant accumulation of 

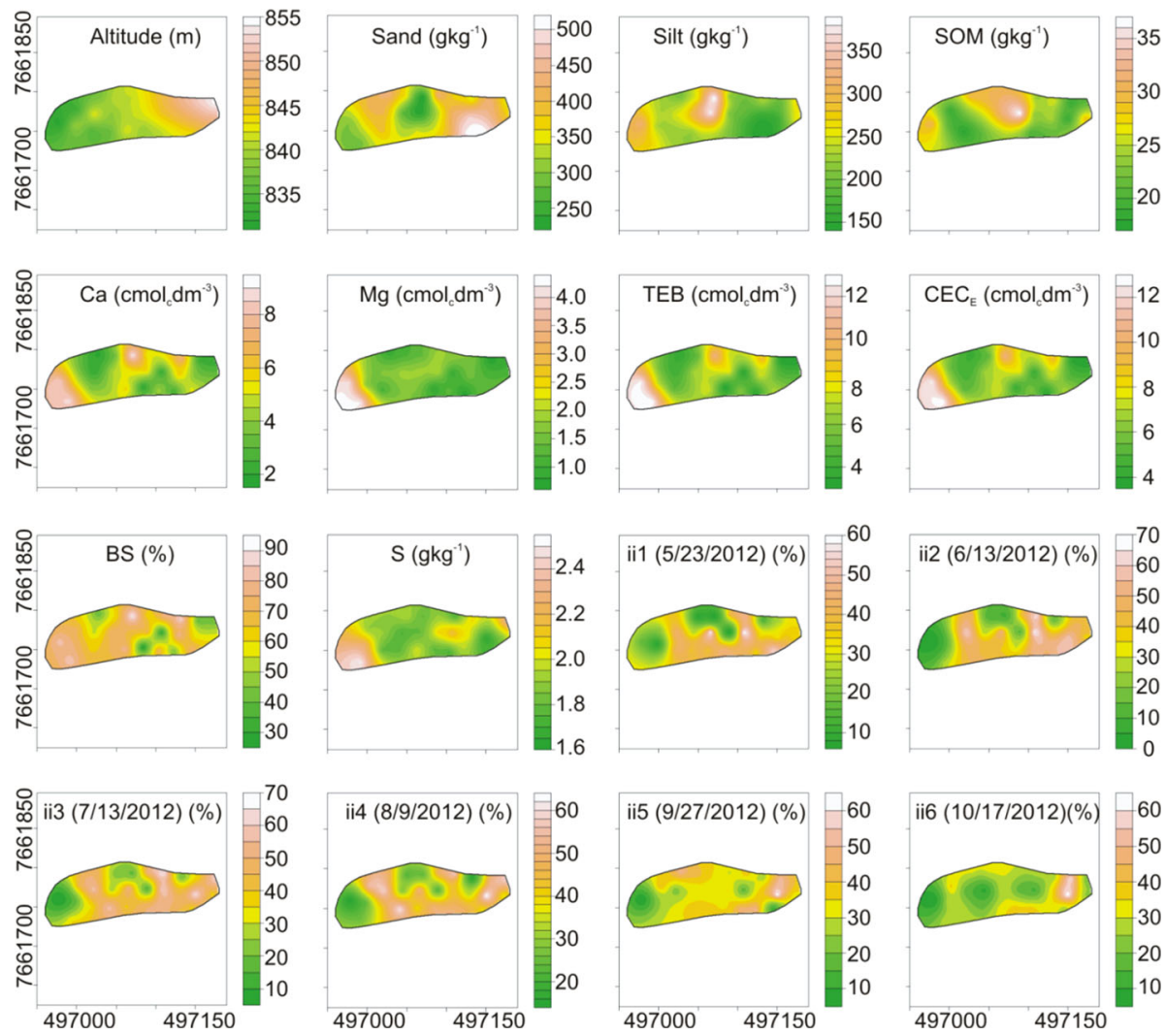

Fig. 5 Kriging maps for altitude, sand level, organic matter (SOM), soil Ca, soil Mg, total exchangeable bases (TEB), effective cation exchange capacity $\left(\mathrm{CEC}_{\mathrm{E}}\right)$, base saturation $(\mathrm{BS})$, foliar sulfur $(\mathrm{S})$ and infection rates assessed on 05/23/2012 (ii1), 06/13/2012 (ii2), 07/13/2012 (ii3), 08/09/2012 (ii4), 09/27/2012 (ii5) and 10/17/2012 (ii6)

organic matter. Kriging maps confirmed these reports; moreover, the lowest infection rate was found in areas with higher levels of TEB, $\mathrm{CEC}_{\mathrm{E}}$, and BS (Fig. 5). Plants in these areas certainly had better development due to greater availability of nutrients, which made them more resistant to disease.

Kriging maps also showed there was a lower infection rate in areas with more $\mathrm{Ca}$ and $\mathrm{Mg}$ in the soil (Fig. 5). Calcium is a major nutrient in the management of plant diseases. Several studies have reported that greater availability of calcium in the soil, leaves, or fruits reduced the incidence and severity of disease in several plant species (Garcia Jr. et al. 2003; Rahman and Punja 2007; Pinheiro et al. 2011). According to Huber et al. (2012), the mechanisms by which calcium affects the incidence of plant diseases are related both to recognition of pathogens invading the plasma membrane and to the stability of cell walls and biomembranes. Only the study of Gerald et al. (2003) reporting a reduction in Yellow Sigatoka in areas with higher levels of $\mathrm{Ca}$ was found in the literature; however, the importance of $\mathrm{Ca}$ in reducing several other pathosystems has been reported. These include coffee (Coffea arabica/coffeicola Cercospora) (Garcia Júnior et al. 2003), citrus (Citrus 
paradisi/Mycosphaerella citri) (Mondal and Timmer 2003) and oak (Quercus ilex/Phytophthora cinnamomi) (Serrano et al. 2013).

Few reports show the effects of Mg on plant diseases (Huber and Jones 2013) since Mg participates in a broad spectrum of general physiological functions that make it difficult to characterize individual activities involved in defense, virulence, and pathogenesis. According to Marschner (2012), among its other activities, magnesium is a constituent of chlorophyll molecule and is necessary for protein synthesis and photosynthesis. Thus, $\mathrm{Mg}$ can affect plant diseases indirectly through the overall health of plants and directly on some specific physiological function. Together with calcium, magnesium is a constituent of the middle lamella and makes it more resistant to degradation by pectolytic enzymes produced by various bacteria and pathogenic fungi (Huber and Jones 2013). Both nutrients had a positive correlation of 0.73 (Table 3), i.e., higher levels of $\mathrm{Mg}$ corresponded with higher levels of $\mathrm{Ca}$ in the soil (Fig. 5). The reduced infection rate of Yellow Sigatoka in soils containing higher levels of $\mathrm{Ca}$ and $\mathrm{Mg}$ (Fig. 5) was significantly associated with increased plant tolerance to $M$. musicola due to these nutrients' ability to protect against disease.
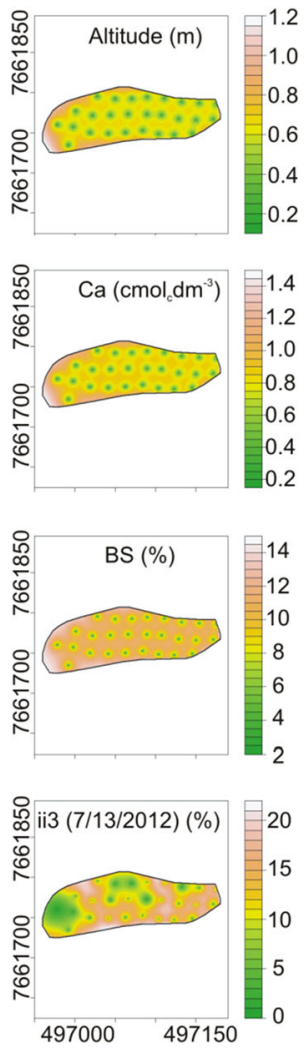
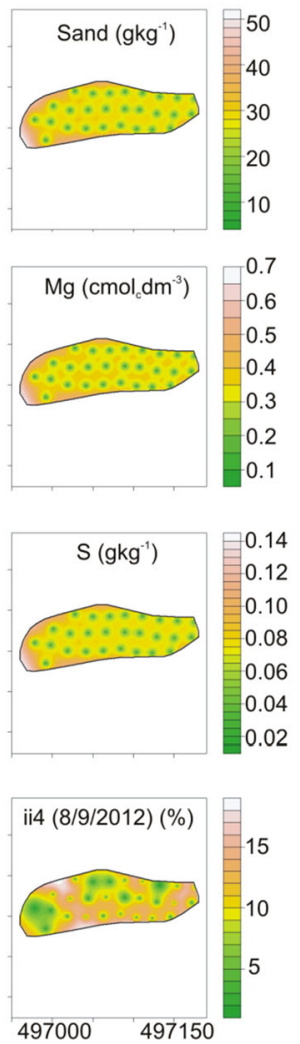
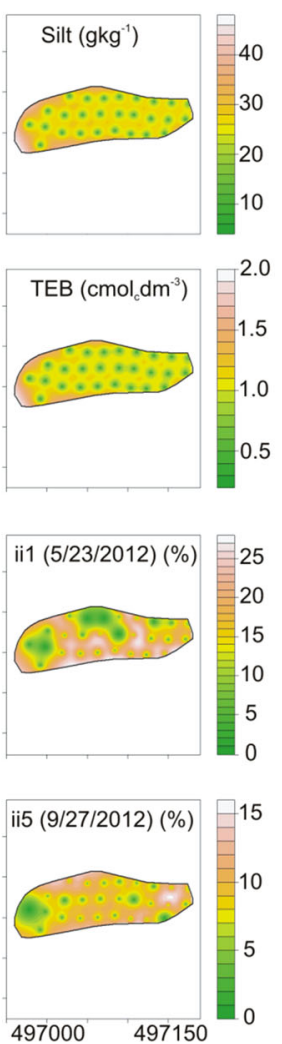
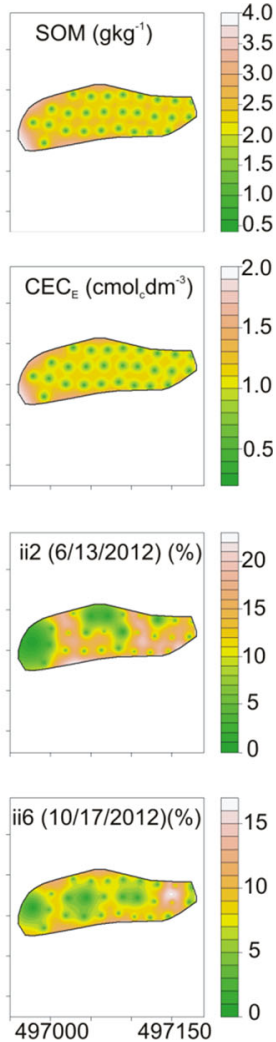

Fig. 6 Kriging error maps for altitude, sand level, organic matter (SOM), soil Ca, soil $\mathrm{Mg}$, total exchangeable bases (TEB), effective cation exchange capacity $\left(\mathrm{CEC}_{\mathrm{E}}\right)$, base saturation (BS), foliar sulfur (S), and infection rates assessed on 05/23/2012 (ii1), 06/13/2012 (ii2), 07/13/2012 (ii3), 08/09/2012 (ii4), 09/27/2012 (ii5) and 10/17/2012 (ii6) 
Kriging maps showed that lower infection rates occurred in leaf areas with higher sulfur levels at all evaluation periods (Fig. 5) and reinforces the importance of this nutrient in plant disease defence. Sulfur increases both plant resistance and the availability of other nutrients (Haneklaus et al. 2007). Furthermore, sulfur in plant metabolism serves various functions to combat attacks by fungi such as the production of toxic compounds, emission of volatile compounds such as $\mathrm{H}_{2} \mathrm{~S}$, dimethyl sulfide and dimethyl disulfide; and the production of glutathione, phytoalexins, and glucosinolates. Salac et al. (2005) reported a lower incidence and severity of Leaf Spot (Pyrenopeziza brassicae) on oilseed rape plants nourished with sulfur. The authors attributed these results to increased levels of glutathione, cysteine, and glucosinolate. Similar results were found by Klikocka et al. (2005), who reported a significant decrease in infection by Rhizoctonia solani and significant increase in production of potato tubers when plants were fed with sulfur. Klikocka (2009) also reported infection and severity of Streptomyces scabies and $R$. solani in potato tubers decreased in areas where sulfur was applied to the soil.

The largest errors of kriging occurred in locations more distant to the sampled points. The highest variance was found for contents of BS and the lowest for infection rates, primarily in evaluations performed on 13/06/2012 (ii2) and 17/10/2012 (ii6) (Fig. 6). The large errors of kriging for BS possibly occurred because this variable shows greater uncertainty in kriging predictions, which is less evident for infection rates. The occurrence of errors is natural because spatial prediction refers to inference about the realization of a process of an unobserved signal (Alves et al. 2012).

\section{Conclusions}

Spatial analysis as used in this study diagnosed areas favorable for the development of Yellow Sigatoka and it was possible to correlate infection rate with soil fertility and plant nutritional status in general.

The spherical model fitted for all variables allowed for spatial prediction of each variable studied using kriging maps.

The highest infection rate was found in areas with more sand, and the lowest in areas with more SOM, TEB, $\mathrm{CEC}_{\mathrm{E}}, \mathrm{BS}, \mathrm{Ca}$ and $\mathrm{Mg}$ in soil, and foliar $\mathrm{S}$.

The results of this study may help farmers manage Yellow Sigatoka more effectively by using balanced fertilization and reduced fungicide applications. This practice can minimize the environmental impact and cost of production, and contribute to the sustainability of production.

Acknowledgments The National Council for Scientific and Technological Development-CNPq provided the Master's scholarship and the Foundation for Research Support of the State of Minas Gerais (FAPEMIG) funded the Project.

\section{References}

Alves, M. C., Pozza, E. A., Machado, J. C., Araújo, D. V., Talamini, V., \& Oliveira, M. S. (2006). Geoestatistics as methodology to study the space-time dynamics of diseases transmitted by seed-borne Colletotrichum spp. Fitopatologia Brasileira, 31(6), 557-563.

Alves, M. C., Pozza, E. A., Silva, F. M., Oliveira, M. S., Carvalho, L. G., \& Sanches, L. (2012). Geoestatística na proteção de plantas: geoinformação do pesquisador ao produtor. Simpósio avanços na otimização do uso de defensivos agrícolas no manejo fitossanitário, 12, 283-302. 
Alves, M. C., Silva, F. M., Moraes, J. C., Pozza, E. A., Oliveira, M. S., Souza, J. C., \& Alves, L. S. (2011). Geostatistical analysis of the spatial variation of the berry borer and leaf miner in a coffee agroecosystem. Precision Agriculture, 12(1), 18-31.

Alves, M. C., Silva, F. M., Pozza, E. A., \& Oliveira, M. S. (2009). Modeling spatial variability and pattern of rust and brown eye spot in coffee agroecosystem. Journal of Pest Science, 82(2), 137-148.

Burrough, P. A., \& McDonnell, R. A. (1998). Principles of geographical information systems. New York: Oxford University Press.

Castelan, F. P., Abadie, C., Hubert, O., Chilin-Charles, Y., De Bellaire, L. L., \& Chillet, M. (2013). Relation between the severity of Sigatoka disease and banana quality characterized by pomological traits and fruit green life. Crop Protection, 50, 61-65.

Cavalcante, E. G. S., Alves, M. C., Pereira, G. T., \& Souza, Z. D. (2007). Spatial variability of MO, P, K and CTC of soil under different use and management conditions. Ciência Rural, 37(2), 394-400.

Cordeiro, Z. J. M., \& Matos, A. P. (2005). Expression of resistance of banana varieties to yellow Sigatoka. Fitopatologia Brasileira, 30(5), 534-535.

Diggle, P. J., \& Ribeiro, P. J, Jr. (2007). Model-based geostatistics. New York: Springer.

Faostat (2014). Food and Agriculture Organization of the United Nations. http://faostat.fao.org/. Retrieved from 23 Sep 2014.

Furtini Neto, A. E., Vale, F. R., Guilherme, L. R. G., \& Guedes, G. A. A. (2001). Fertilidade do solo e nutrição de plantas no agronegócio. Lavras: UFLA/FAEPE.

Garcia Júnior, D., Pozza, E. A., Pozza, A. A., Souza, P. E., Carvalho, J. G., \& Balieiro, A. C. (2003). Incidence and severity of the brown eye spot of coffee according to supply of potassium and calcium in nutrient solution. Fitopatologia Brasileira, 28(3), 286-291.

Gauhl, F. (1994). Epidemiology and Ecology of Black Sigatoka (Mycosphaerella fijiensis Morelet) on Plantain nad banana (Musa spp) in Costa Rica, Central América. Montpellier: INIBAP.

Gerald, S. F., White, S. D., Dickinson, A. A., \& Goldman, B. (2003). A survey of Sigatoka leaf disease (Mycosphaerella musicola Leach) of banana and soil calcium levels in North Queensland. Animal Production Science, 43(9), 1157-1161.

Haneklaus, S., Bloem, E., \& Schnug, E. (2007). Sulfur and plant disease. In L. E. Datnoff, W. H. Elmer, \& D. M. Huber (Eds.), Mineral nutrition and plant disease (pp. 101-118). Saint Paul: The American Phytopathological Society.

Huber, D. M., \& Jones, J. B. (2013). The role of magnesium in plant disease. Plant and Soil, 368(1-2), 73-85.

Huber, D., Römheld, V., \& Weinmann, M. (2012). Relationship between nutrition, plant diseases and pests. In H. Marschner (Ed.), Mineral Nutrition of Higher Plants (3rd ed., pp. 283-298). San Diego: Academic Press.

Jaime-Garcia, R., Orum, T. V., Felix-Gastelum, R., Trinidad-Correa, R., Vanetten, H. D., \& Nelson, M. R. (2001). Spatial analysis of Phytophthora infestans genotypes and late blight severity on tomato and potato in the Del Fuerte Valley using geostatistics and geographic information systems. Phytopathology, 91(12), 1156-1165.

Klikocka, H. (2009). Influence of NPK fertilization enriched with S, Mg, and micronutrients contained in liquid fertilizer Insol 7 on potato tubers yield (Solanum tuberosum L.) and infestation of tubers with Streptomyces scabies and Rhizoctonia solani. Journal of Elementology, 14(2), 271-288.

Klikocka, H., Haneklaus, S., Bloem, E., \& Schnug, E. (2005). Influence of sulfur fertilization on infection of potato tubers with Rhizoctonia solani and Streptomyces scabies. Journal of Plant Nutrition, 28(5), 819-833.

Lamichhane, J. R., Fabi, A., Ridolfi, R., \& Varvaro, L. (2013). Epidemiological study of Hazelnut bacterial blight in Central Italy by using laboratory analysis and geostatistics. PLoS One, 8(2), 1-14.

Li, B. N., Cao, R., Chen, L., Zhou, Y., Duan, X., Luo, Y., et al. (2013). Application of geographic information systems to Identify the oversummering regions of Blumeria graminis f. sp. tritici in China. Plant Disease, 97(9), 1168-1174.

Lima, L. M. D., Pozza, E. A., Torres, H. N., Pozza, A. A., Salgado, M., \& Pfenning, L. H. (2010). Relationship between nitrogen/potassium with Phoma spot and nutrition of coffee seedlings cultivated in nutrient solution. Tropical Plant Pathology, 35(4), 223-228.

Marschner, H. (2012). Mineral nutrition of higher plants (3rd ed., p. 643). San Diego: Academic Press.

Martinez, H. E. P., Carvalho, J. G., \& Souza, R. B. (1999). Diagnose foliar. In A. C. Ribeiro, P. T. G. Guimarães, \& V. V. H. Alvarez (Eds.), Recomendações para uso de corretivos e fertilizantes em Minas Gerais. $5^{a}$ aproximação (pp. 143-168). Viçosa: CFSEMG.

Mcbratney, A. B., \& Webster, R. (1983). How many observations are needed for regional estimation of soil properties? Soil Science, Baltimore, 135(3), 177-183. 
McBratney, A. B., \& Webster, R. (1986). Choosing functions for semi-variograms of soil properties and fitting them to sampling estimates. Journal Soil Science, 37(4), 617-639.

Mohamed, Z., Abdlatif, I., Abdullah, A. M., \& Yahia, E. M. (2011). Economic importance of tropical and subtropical fruits. Postharvest biology and technology of tropical and subtropical fruits, 1, 1-20.

Mondal, S. N., \& Timmer, L. W. (2003). Effect of urea, $\mathrm{CaCO}_{3}$, and dolomite on pseudothecial development and ascospore production of Mycosphaerella citri. Plant Disease, 87(5), 478-483.

Olea, R. A. (2003). Geostatistics for engineers and earth scientists. Norwell: Kluwer Academic Publishers.

Pardo-Igúzquiza, E. (1998). Inference of spatial indicator covariance parameters by maximum likelihood using MLREML. Computers \& Geosciences, 24(5), 453-464.

Pinheiro, J. B., Pozza, E. A., Pozza, A. A. A., Moreira, A. S., \& Alves, M. C. (2011). Effect of potassium and calcium supplied via nutrient solution on the severity of Asian soybean rust. Revista Ceres, 58(1), 43-50.

Pinheiro, J. B., Pozza, E. A., Pozza, A. A. A., Moreira, A. S., Alves, M. D. C., \& Campos, V. P. (2008). Influence of mineral nutrition on the spatial distribution of soybean cyst nematode. Nematologia Brasileira, 32(4), 270-278.

Rahman, M., \& Punja, Z. K. (2007). Calcium and plant disease. In L. E. Datnoff, W. H. Elmer, \& D. M. Huber (Eds.), Mineral nutrition and plant disease (pp. 79-93). Saint Paul: The American Phytopathological Society.

Rocha, H. S., Pozza, E. A., Uchôa, C. D. N., Cordeiro, Z. J. M., Souza, P. E., Sussel, Â. A. B., \& Rezende, C. A. (2012). Temporal Progress of Yellow Sigatoka and Aerobiology of Mycosphaerella musicola Spores. Journal of Phytopathology, 160(6), 277-285.

Salac, I., Haneklaus, S. H., Bloem, E., Booth, E. J., Sutherland, K. G., Walker, K. C., \& Schnug, E. (2005). Sulfur nutrition and its significance for crop resistance: a case study from Scotland. Landbauforschung Volkenrode, 283, 111-119.

Serrano, M. S., Fernández-Rebollo, P., Vita, P., \& Sánchez, M. E. (2013). Calcium mineral nutrition increases the tolerance of Quercus ilex to Phytophthora root disease affecting oak rangeland ecosystems in Spain. Agroforestry Systems, 87(1), 173-179.

Silva, J. T. A., Borges, A. L., Dias, M. S. C., Costa, E. L., \& Prudêncio, J. M. (2002). Diagnóstico nutricional da bananeira prata anã para o norte de Minas (p. 16). Belo Horizonte: EPAMIG. (Boletim Técnico, 70).

Silva, J. T. A., Borges, A. L., \& Malburg, J. L. (1999). Solos, adubação e nutrição da bananeira. Informe agropecuário, Belo Horizonte, 20(196), 21-36.

Silva, J. T. A., Pacheco, D. D., \& Costa, É. L. (2007). Chemical and physical properties of soil cultivated with dwarf prata banana tree (aab), in three levels of productivity, in the north of minas gerais. Revista Brasileira de Fruticultura, 29(1), 102-106.

Stover, R. H. (1972). Banana, Plantain and Abaca Diseases. Kew: Commonwealth Mycological Institute.

Taiz, L., \& Zeiger, E. (2013). Fisiologia vegetal (5th ed., p. 918). Porto Alegre: Artmed.

Uchôa, C. N., Pozza, E. A., Pozza, A. A. A., \& Moraes, W. S. (2011). Geostatistical modeling of blacksigatoka and relation to soil fertility. Bioscience Journal, 27(3), 357-362.

Wardlaw, C. W. (1961). Leaf spot (Sigatoka Disease). In C. W. Wardlaw (Ed.), Banana Diseases: Including Plantains and Abaca (Vol. 11, pp. 314-341). Edingburgh: Longman.

Webster, R., \& Oliver, M. (2007). Sample adequately to estimate variograms of soil properties. Journal of Soil Science, 43, 177-192. 